Journal of Animal \& Plant Sciences, 31(6): 2021, Page: 1772-1778

ISSN (print): 1018-7081; ISSN (online): 2309-8694

https://doi.org/10.36899/JAPS.2021.6.0381

\title{
AN EMPIRICAL INVESTIGATION OF MISPERCEPTIONS ABOUT BROILER MEAT CONSUMERS
}

\author{
R. M. Ayyub, M. Bilal, M. A. Hamza, and S. Naeem \\ UVAS Business School, Faculty of Life Sciences Business Management, University of Veterinary and Animal Sciences, \\ Lahore. \\ Corresponding author's email: drranaayyub@uvas.edu.pk
}

\begin{abstract}
The purpose of this study was to empirically evaluate and study the misconceptions hovering in the minds of people regarding the broiler chicken and its meat. In this study, quantitative data was collected through questionnaire surveys from 498 consumers randomly from nine towns of Lahore by adopting a cluster sampling technique. The data were analyzed through Excel software by using a pivot table technique. The results showed that consumers have many reservations regarding broiler meat available in the market. These include reservations regarding the type of feed given, usage of antibiotics/hormones, and speedy growth, etc. The results are presented in the form of tables, graphs, and pie charts. It is recommended that a national campaign must be launched to educate the consumers about the realities of the broiler industry to overcome prevailing misperceptions of consumers otherwise these consumers will gradually leave broiler meat. Finally, this situation will lead to severe protein deficiency among the general public of Pakistan leading to aggravating food insecurity. The findings of this study will guide industrialist, poultry farmers and marketers to develop and refine their marketing strategies to reduce misperceptions and increase the acceptability of broiler meat.
\end{abstract}

Key Words: Broiler, Broiler meat, Misperceptions, Protein deficiency, Food insecurity Published first online March 31, 2021

Published final Nov. 20, 2021.

\section{INTRODUCTION}

The poultry industry of Pakistan has been performing extraordinarily well locally and internationally as compared to other livestock businesses since the last decade. It is the second largest industry of Pakistan which can be considered as one of the major gear of Pakistani economy as it contributes around 1.3\% to the Pakistani GDP (Anonymous 2018). It has resulted in mushroom growth of various poultry-related businesses like broiler farming, layer farming, breeder, and allied businesses. Among these, the broiler business is considered the first point of contact for the common people of Pakistan. The broiler meat is considered the cheapest and easily available meat which fulfills the protein requirements of people especially the poor which makes the major class in Pakistan (Zia 2016, Recorder 2013, Correspondents 2014). Quite recently, some misunderstandings have been prevailing among various segments of Pakistani markets who are not only avoiding broiler meat by themselves rather they are involved in negative propaganda against it (Ayyub et al., 2020). This situation has a bad impact on broiler meat consumption as well as business in Pakistan for the last couple of years.

Since the start of this century, the Poultry industry was reshaped on scientific grounds by the introduction of technological advancements regarding machinery, vaccination, farming practices (Havenstein et al., 2003), genetic improvements, medication, and housing (ThePoultrySite 2016). Perhaps the consumers were of the view that poultry industrialists were introducing all these reforms to increase their profits/earnings at the cost of consumers (Association 2016). Thus a lot of misperceptions started prevailing in the market and consumers. For instance; different spokesmen, nutritionists, doctors, media persons, social activists raised their voices against the various aspects of the broiler industry including excessive use of medicines and hormones in poultry as they are directly linked with human health (Hussein and Khalil 2013). Likewise, Erian and Phillips (2017) concluded that public understanding of chicken meat production and the way it impacts their attitude and behavior towards its consumption is still an untapped area. Social activists, the general public, especially parents joined with "The international thunderclap campaign" by raising posters with the written slogan "Antibiotic off The Menu" on social media pages and in front of these fast-food chains (Reporter 2016a, Qureshi 2016). Such negative word of mouth (WOM) campaigns have become a routine matter in print, social and electronic media (Ettinger 2011, PETA 2011, Editor 2014, Khan 2016, Mukhtar 2016).

This fact justifies the need for this study and brings us to our problem statement that why some segments of the Pakistani market are avoiding broiler meat and spreading negative word of mouth against it? So far, there is no comprehensive empirical study to explore the consumer behavior of such segments of the 
market in the Pakistani context. The main purpose of this study was to empirically study these perceptions of consumers about broiler poultry meat in Pakistan.

\section{MATERIALS AND METHODS}

For this quantitative study, a questionnaire instrument was designed to collect the responses from the general consumers through mall intercept method. The respondents were general consumers of broiler meat and it's products mainly from Lahore, Punjab, Pakistan. The covered area included nine administrative towns of Lahore to get the representative sample. As per the directions, of the funding agency, the data were collected from Lahore only. The main reason behind this was that in Lahore people from almost all the other cities of Punjab and even from other provinces come and reside for various reasons including job, education, dealing legal issues, leisure and administrative matters. The data were collected through random sampling using a survey questionnaire (Hair et al., 2010) to access the consumer behaviour about the broiler meat. Under provision of the funding of project, a total of 10 enumerators were hired and trained for the data collection who collected the data from nine administrative towns of Lahore with at least 55 questionnaires from each town. The total population of Lahore is around twelve million so the representative sample size becomes 400 as per calculations of sample size formula proposed by Yamane (1967). Thus required sample size from each town becomes around more than 55 from each town on equal allocation basis (see for example; Bowley 1926, Rao 1968, Choudhry et al., 2012). The dempgraphic details of respondents regarding age include respondents having less than 18 years $(7.5 \%)$, between 18 to 35 years $(66.6 \%)$, between 36 to 50 years $(20 \%)$ and over 50 years $(5.9 \%)$. Likewise, the demographic details of sample regarding educational status of respondents include less than high school (14.8\%), High school (19.9\%), Bachelor degree holders (43.1\%) and Master/PhD degree holders (22.3\%). The respondents were asked to rank their response to questions as ranked order sequence. Out of collected questionnaires, after necessary screening, a total of 498 questionnaires were included for analysis. The results were analyzed through a pivot table and presented in the results section (Grech 2018).

\section{RESULTS}

The results show that consumers have a lot of reservations regarding broiler meat available in the market of Lahore. These reservations include that Broiler is fed with a very unhealthy feed having waste materials from different industries including blood, fish, feathers, dead material, etc. Secondly they consider that a Broiler is given excessive medications i.e. antibiotics and even hormones thus the usage of broiler meat is injurious for human consumption. Thirdly, it was found that consumers think that the fast growth of Broilers, in just around 40 days, is deadly against nature and its principles thus it results in the unnatural occurrence of different diseases in humans. When the consumers were asked that do they have any authentic or scientific grounds for all these claims so almost everybody responded that they don't, rather they told that the main source of their information is the general public or media. On the other hand, the majority of consumers told that they have either switched to organic Broiler being marketed by some of the marketers or thinking to do so. Lastly, the majority of consumers explain that Broiler meat is a cheaper source of protein in Pakistan where the pulses are sometimes costlier than chicken but sometimes they further demanded that the prices must be regulated and lowered down. Finally, the majority of respondents showed their concerns that they are being alienated from Broiler meat under the ambit of all these misperceptions among them. The respondents were asked to rank the type of their reservation on a 7 rank order scale and the results are summarized in the table given below.

Table 1: Overall response to each option in Rank order scale regarding the type of reservations.

\begin{tabular}{cccccccc}
\hline $\begin{array}{c}\text { Ranking in } \\
\text { Order Scale }\end{array}$ & $\begin{array}{c}\text { Count of } \\
\text { Quality }\end{array}$ & $\begin{array}{c}\text { Count of } \\
\text { Antibiotic }\end{array}$ & $\begin{array}{c}\text { Count of } \\
\text { Hormones }\end{array}$ & $\begin{array}{c}\text { Count of } \\
\text { Unhygienic }\end{array}$ & $\begin{array}{c}\text { Count of } \\
\text { Waste in feed }\end{array}$ & $\begin{array}{c}\text { Count of } \\
\text { Fast Growth }\end{array}$ & $\begin{array}{c}\text { Count of } \\
\text { Puberty }\end{array}$ \\
\hline 1(Highest) & 42 & 54 & 64 & 76 & 68 & 118 & 86 \\
2 & 76 & 68 & 96 & 66 & 84 & 28 & 82 \\
3 & 62 & 78 & 86 & 80 & 50 & 80 & 66 \\
4 & 78 & 82 & 82 & 88 & 66 & 50 & 56 \\
5 & 90 & 104 & 74 & 56 & 82 & 28 & 66 \\
6 & 60 & 72 & 62 & 84 & 68 & 78 & 58 \\
7 (Lowest) & 90 & 40 & 34 & 48 & 80 & 116 & 84 \\
Total & $\mathbf{4 9 8}$ & $\mathbf{4 9 8}$ & $\mathbf{4 9 8}$ & $\mathbf{4 9 8}$ & $\mathbf{4 9 8}$ & $\mathbf{4 9 8}$ & $\mathbf{4 9 8}$ \\
\hline
\end{tabular}


Explanation of Results through Pivot Table: The above table shows that when respondents $(n=498)$ were asked about giving rank to the reasons of their perceptions towards Broiler meat as per their perceptions, they gave different responses. The result was summarized using a Pivot table from Excel. For each rank, two topmost responses were highlighted in the table. The explanation can be narrated as follows.

1. The topmost reservation of being alienated towards Broiler meat was "un-natural fast growth of broiler" $(\mathrm{n}=118)$ and "cause of Early Puberty in males \& females" $(n=86)$. It means that 118 respondents told that they do not like Broiler because it grows very fast which is against nature and raises a lot of questions. Secondly, 86 respondents told that they don't like Broiler because it causes early puberty in males and females which is harmful to our coming generations.

2. The second topmost reservation of being alienated towards Broiler meat was "Use of hormones for broiler" $(n=96)$ and "Use of unhygienic waste material from various industries" $(\mathrm{n}=84)$. It means that 96 respondents told that they do not like Broiler because excessive hormones are used in Broilers production which is injurious to human health. Secondly, 84 respondents told that they don't like Broiler because a variety of waste material from various industries is used in the production of feed of broilers which causes a lot of healthhazardous for human consumption.

3. The third topmost reservation of being alienated towards Broiler meat was "Use of hormones for broiler" ( $\mathrm{n}=86)$ and "Unhygienic environment for broiler" $(\mathrm{n}=80)$. It means that 86 respondents told that they do not like Broiler because excessive hormones are used in Broilers production which is injurious to human health. Secondly, 80 respondents told that they don't like Broiler because the broiler is raised and kept in a very unhealthy environment which is not good for human consumption. This response shows that excessive usage of hormones is a very important alienating factor among respondents as it is ranked as second as well as the third option.

4. The fourth top most reservation of being alienated towards Broiler meat was "Unhygienic environment for broiler" $(\mathrm{n}=86)$ and "Use of hormones for broiler" $(\mathrm{n}=82)$ and "Use of antibiotics for broiler" $(\mathrm{n}=82)$. It means that 86 respondents told that they don't like Broiler because the broiler is raised and kept in a very unhealthy environment which is not good for human consumption. Secondly, 82 respondents told that they do not like Broiler because excessive hormones are used in Broilers production and the same number of respondents $(n=82)$ responded that excessive antibiotics are used in broiler production, which is injurious to human health. This response shows that unhygienic environmental conditions and excessive usage of hormones are very important alienating factors among respondents as these were ranked as a third top reason too.

5. The fifth top most reservation of being alienated towards Broiler meat was "Use of antibiotics for broiler" $(n=104)$ and $(n=86)$ and "Low quality of broiler meat" $(\mathrm{n}=90)$. It means that 104 respondents responded that excessive antibiotics are used in broiler production, which is injurious to human health. Secondly, 90 responded that they don't use Broiler because the quality of broiler meat is not good. This response shows that excessive usage of antibiotics is very important in alienating factors among respondents as it was ranked as the fourth top reason too.

6. The sixth top most reservation of being alienated towards Broiler meat was "Unhygienic environment for broiler" $(\mathrm{n}=84)$ and "Fast growth of Broiler" $(n=78)$. It means that 84 respondents told that they don't like Broiler because the broiler is raised and kept in a very unhealthy environment which is not good for human consumption. Secondly, 78 respondents told that they do not like Broiler because the fast growth of the broiler is against nature and definitely will have some repercussions against human health. This response shows that unhygienic environmental conditions and fast growth rate of Broiler are very important alienating factors among respondents as these were ranked top reasons earlier too.

7. The seventh top most reservation of being alienated towards Broiler meat was "Fast growth rate of Broiler" $(n=116)$ and "Quality of Broiler meat" $(n=90)$. It means that 116 respondents told that they don't like Broiler because its fast growth is against nature and can bring disastrous effects on human health. Secondly, 90 respondents told that they do not like Broiler because the quality of Broiler meat is not good. This response shows that fast growth and Low quality of Broiler meat are very important alienating factors among respondents as these were ranked as top reasons earlier too. The above results can be summarized in the following way: 
Table no.2: Top two in each rank order.

\begin{tabular}{|c|c|c|c|c|c|c|c|}
\hline $\begin{array}{l}\text { Ranking in } \\
\text { Order } \\
\text { Scale }\end{array}$ & $\begin{array}{l}\text { Count of } \\
\text { Quality }\end{array}$ & $\begin{array}{c}\text { Count of } \\
\text { Antibiotic }\end{array}$ & $\begin{array}{l}\text { Count of } \\
\text { Hormones }\end{array}$ & $\begin{array}{l}\text { Count of } \\
\text { Unhygienic }\end{array}$ & $\begin{array}{c}\text { Count of } \\
\text { Waste in } \\
\text { feed }\end{array}$ & $\begin{array}{c}\text { Count of } \\
\text { Fast } \\
\text { Growth } \\
\end{array}$ & $\begin{array}{l}\text { Count of } \\
\text { Puberty }\end{array}$ \\
\hline 1 & & & & & & 118 & 86 \\
\hline 2 & & & 96 & & 84 & & \\
\hline 3 & & & 86 & 80 & & 80 & \\
\hline 4 & & 82 & 82 & 88 & & & \\
\hline 5 & 90 & 104 & & & & & \\
\hline 6 & & & & 84 & & 78 & \\
\hline 7 & 90 & & & & & 116 & \\
\hline Out of Total & $180 / 498$ & $186 / 498$ & $426 / 498$ & $252 / 498$ & $84 / 498$ & $392 / 498$ & $86 / 498$ \\
\hline
\end{tabular}

Table no.3: Top one in each rank order.

\begin{tabular}{llllllll}
\hline $\begin{array}{l}\text { Ranking in } \\
\text { Order Scale }\end{array}$ & $\begin{array}{l}\text { Count of } \\
\text { Quality }\end{array}$ & $\begin{array}{l}\text { Count of } \\
\text { Antibiotic }\end{array}$ & $\begin{array}{l}\text { Count of } \\
\text { Hormones }\end{array}$ & $\begin{array}{l}\text { Count of } \\
\text { Unhygienic }\end{array}$ & $\begin{array}{l}\text { Count of } \\
\text { Waste in } \\
\text { feed }\end{array}$ & $\begin{array}{l}\text { Count of } \\
\text { Fast Growth }\end{array}$ & $\begin{array}{l}\text { Count of } \\
\text { Puberty }\end{array}$ \\
\hline 1 & & & 96 & & & 118 & \\
2 & & & 86 & 88 & & & \\
3 & & & & & & & \\
4 & 104 & & 84 & & 116 & 498 \\
5 & & 498 & 498 & 498 & 498 & 498 & 498 \\
\hline
\end{tabular}

Fig 1: Results description of top rank regarding the type of reservation through Pie chart

Fig. 2: Results description of rank orders regarding the type of reservation through Bar Chart

Response regarding the source of InformationResults: In the questionnaire, the respondents were asked about their source of information about broiler meat and industry among four given options i.e. Media, Friends, any research source, and non-confident about the information they have. The detailed counts against each information source are given in a table below:

Table no.4: Response to rank order question regarding the source of information.

\begin{tabular}{ccccc}
\hline Row Labels & Count of Media & Count of Friends & Count of Research & Count of None Confident \\
\hline 1 & 150 & 132 & 116 & 98 \\
2 & 130 & 174 & 124 & 70 \\
3 & 102 & 132 & 138 & 122 \\
4 & 116 & 60 & 120 & 208 \\
Grand Total & $\mathbf{4 9 8}$ & $\mathbf{4 9 8}$ & $\mathbf{4 9 8}$ & $\mathbf{4 9 8}$ \\
\hline
\end{tabular}

The above table shows that the sources of information are varied but can be summarized in the following way:

1. The topmost rank was given to Media as a source of information, as 150 respondents gave it as the main source of their information about alienating factors regarding Broiler chicks.

2. The second topmost rank was given to friends as 174 respondents gave it the second top source of their information about alienating factors regarding Broiler chicks.
3. The third topmost rank was given to research source as 138 respondents gave it the third top source of their information about alienating factors regarding Broiler chicks. It means that only a few people have tried any authentic source to confirm their information.

4. The fourth rank was given to non-confident about their information as 208 respondents gave it the fourth rank of their information about alienating factors regarding Broiler chicks. It means that majority of people were not 
confident about their information but were

having and spreading it without any authenticity.

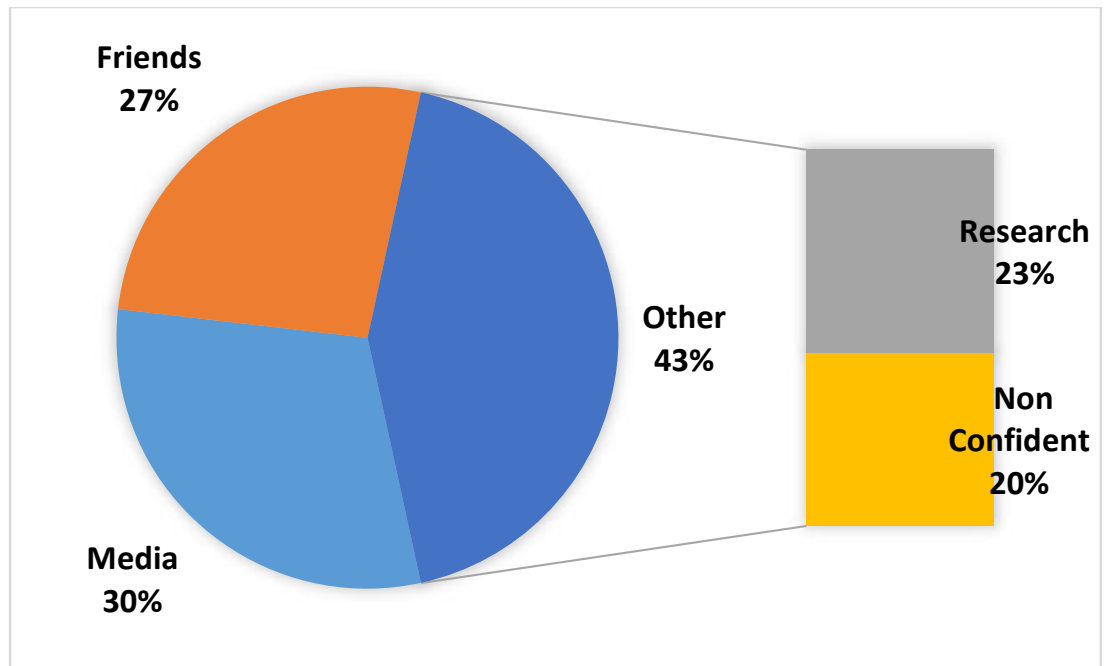

Fig. 3: Results description of top rank regarding the source of information through Pie chart

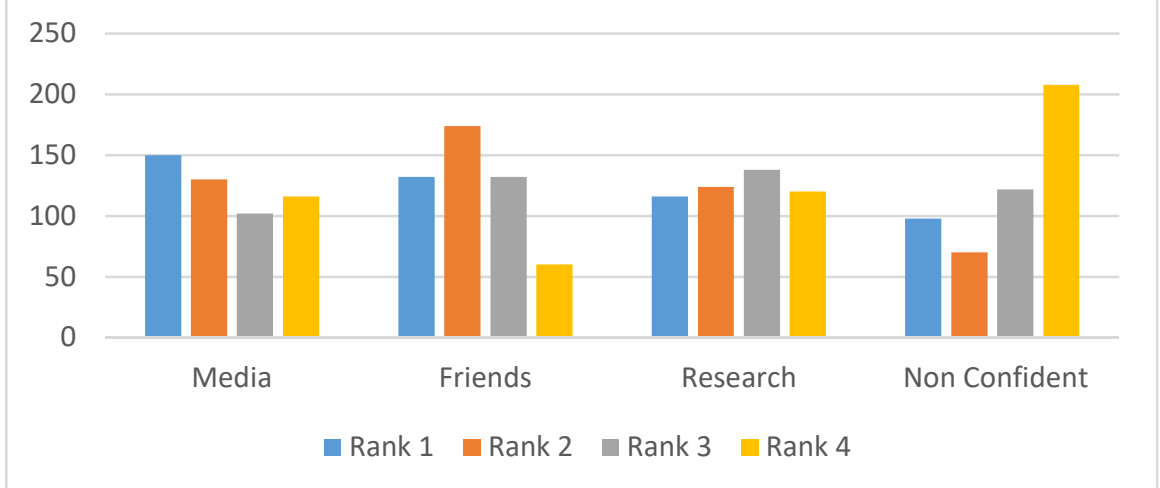

Fig.4: Results description of rank orders regarding the source of information through Bar chart

\section{DISCUSSION}

Perception regarding broiler meat was explored in the general public. The findings of the qualitative study indicate that the majority of the people have negative perceptions regarding broiler meat and its products (Wegener 2003, Ettinger 2011). Regarding the quality of broiler meat and its products, the general public considers it unsafe and unhealthy which is consistent with findings of reports presented in the literature review (Havenstein et al. 2003, Njidam et al. 2005). This work provides empirical evidence that general public/consumers of Pakistan consider poultry meat as unsafe and unhealthy food which is consistent with the earlier studies presented in the literature review (Ettinger 2011, PETA 2011).

It was also found that consumers have misperceptions about broiler meat which they get from their societal sources including media, friends, and social circles. It has been found in a short questionnaire survey that most of the consumers indicated that they have not done any kind of research for confirming bad things about broiler rather their main source of information is media and friends (Reporter 2016b). These findings are also in line with the previous reports. Furthermore, the majority of respondents shown their willingness to know the reality of all these misperceptions through authentic sources. This apprises the fact that people are not stubborn about their thinking regarding broiler meat rather willing to reach the in-depth realities of the poultry industry. These highlighted concerns of consumers are also evident from other studies mentioned in the literature (Ettinger 2011, PETA 2011, Khan 2016). Thus, it was concluded that the concerns of consumers must be addressed properly to avoid boycott calls from consumers.

Based on the above findings it is recommended that a national campaign must be launched to educate the consumers about prevailing misperceptions of consumers otherwise consumers will gradually leave broiler meat. Such a campaign should cater to misperceptions regarding the genetic makeup of the broiler bird, its supply chain, speedy growth, feeding contents, medication requirement/modalities, and farm practices 
(PETA 2011, Khan 2016, Qureshi 2016). It is further claimed that these empirical findings will appraise all stakeholders about the importance of misperceptions of people about Broiler meat. It is further expected that the findings of this study will guide industrialist, poultry farmers and marketers to refine their marketing strategies to reduce consumer alienation and increase the acceptability of Broiler meat in the prevailing market scenario. These findings have very important implications for managing the resistances against broiler meat perception.

Recommendations: Based on the findings of this research study, the following recommendations are made:

1. A campaign must be launched on the National level to educate the consumers about prevailing misperceptions of consumers otherwise consumers will gradually leave broiler meat. Such a campaign should cater to the following perceptions hovering among consumers:

a. People should be educated that the fast growth of Broiler is not against rules of nature rather it is the result of the struggle of scientists for bringing required changes in the genetic makeup of broiler breeds which have enabled it to grow fast.

b. The misperceptions regarding the inclusion of unhealthy ingredients like blood, fish, waste of other industries, and even some dead materials should also be removed.

c. The misperceptions regarding excessive medication like antibiotics should also be justified based on the nature of business and its requirements.

d. The misperceptions regarding excessive usage of hormones should also be removed as no such practice is used in farm practices.

e. The misperceptions regarding excessive vaccination should also be justified based on the type of business.

f. The misperceptions regarding the cruel supply chain of Broiler should also be removed because the industry requires to make it more efficient.

2. Some experimental studies must be conducted in medical sciences which can show either broiler meat cause problems like early puberty, infectious or cancerous diseases, or otherwise. For this purpose, longitudinal studies should be conducted for accurate data. These studies can be done in medical or social sciences disciplines.

3. Consumers must be exposed to various scientific practices by arranging their tours in a model or corporate farms, feed mills, and hatcheries.
4. Some documentary movies regarding farm practices in the broiler industry must be launched on national media.

5. An open-door policy for farms and sheds should be adopted to give easy access to people particularly opinion leaders (e.g. Medical doctors, Lawyers, media activists) of the society.

6. The youth particularly students of schools, colleges, and universities must be extensively pursued because they are they may be the game changers for building positive word of mouth through social media.

7. Some regular talk shows should be initiated on National electronic and print media for bridging this gap of communication.

8. The professional organizations like PPA (Pakistan Poultry Association) must take lead in correcting perceptions of people regarding Broiler because the small/individual farmers do not bother to step into this long struggle.

\section{Implications}

Practical implications: The outcome of this study will guide broiler industrialists and PPA (Pakistan Poultry Association) to adopt the required strategic planning regarding the effective marketing of broiler poultry in Pakistan. It will enable industrialists to increase their business volume which will ultimately help them to boost the economic growth of Pakistan. The trickle-down effect of this predicted economic growth and development will result in technological advancement and targeting unexplored market opportunities for the Pakistani broiler industry.

Policy guidelines: The results of this study will help PPA (Pakistan Poultry Association) and Government officials in policy parlors to devise appropriate policy guidelines regarding effective marketing of the broiler industry of Pakistan on National media including print, electronic and social media.

Limitations and future research directions: This study has a couple of limitations too. For instance, the quantitative data was collected only from one city and some of its peripheries i.e. Lahore. The research could be conducted by adding some more reliable constructs for more deep analysis and results. Another limitation of this study is the shortage of time for data collection. As far as future directions are concerned, the findings of this study can guide future researchers to point out the hidden loopholes in the system; and guide the stakeholders of the poultry industry to refine their marketing strategies to increase consumption of Broiler among Pakistani markets. Several studies can be designed where consumers can be further studied in depth for each of their reservations particularly through experimental design. Such results will be very helpful for the 
stakeholders. As suggested earlier, some research projects can be designed in continuity to ongoing experimental longitudinal studies of the medical filed where consumer behavior can be studied in detail.

Acknowledgment of funding agency: This research project has been funded by Pakistan Poultry Association (PPA) to the UVAS Business School, Lahore. PPA gave a mandate to empirically study the prevailing perceptions of people about broiler poultry meat and resultant consumer alienation towards its consumption within Punjab.

\section{REFERENCES}

Anonymous (2018). Pakistan Economic Survey. G. o. P. Finance Division. Islamabad, Economic Advisor's Wing.

Association, P. P. (2016). History of Poultry Industry: Talking About Poultry Industry of Pakistan. from

http://www.pakistanpoultryassociationnz.pk/pou ltry-industries/history-of-poultry-industry/.

Ayyub, R. M., S. Naeem, S. Ahmed and C. Jayawardhena (2020). Investigating Consumer alienation towards Broiler leading to food insecurity. British Food J. https://doi.org/10.1108/BFJ-072020-0616 (Ahead of publication).

Bowley, A. (1926). An Introduction to the Methods of Economic Statistics, The Economic J. 36(142): 272-274.

Choudhry, G. H., J. Rao and M. A. Hidiroglou (2012). On sample allocation for efficient domain estimation. Survey Methodology 38(1): 23-29.

Correspondents (2014). Reflecting on nutrition: 'Poultry an affordable source of potein'. The Express Tribune (October).

Editor, W. (2014). 5 dangerous disadvantages of broiler chicken. from http://www.pakistantv.tv/ 2014/07/23/5-dangerous-disadvantages-broilerchicken/.

Erian, I. and C. J. Phillips (2017). "Public understanding and attitudes towards meat chicken production and relations to consumption." Animals 7(3): 20.

Ettinger, J. (2011). 8 Reasons Chicken Is Not A Health Food.

http://www.organicauthority.com/health/8reasons-chicken-is-not-a-health-food.html.2020.

Grech, V. (2018). WASP (Write a Scientific Paper) using Excel-2: Pivot tables. Early human development 117: 104-109.

Hair, J. F. J., W. C. Black, B. J. Babin, R. E. Anderson and R. L. Tatham (2010). Multivariate data analysis New Jersey, Pearson Education.
Havenstein, G., P. Ferket and M. Qureshi (2003). Growth, livability, and feed conversion of 1957 versus 2001 broilers when fed representative 1957 and 2001 broiler diets. Poult Sci 82(10): 1500-1508.

Hussein, M. A. and S. Khalil (2013). "Screening of some antibiotics and anabolic steroids residues in broiler fillet marketed in El-Sharkia governorate." Life Sci J 10(1): 2111-2118.

Khan, M. (2016) "5 Hidden dangers of eating chicken."

Mukhtar, I. (2016). Excessive use of antibiotics in poultry unhygienic. The Nations. Islamabad, Pakistan.

Njidam, E., E. Delezie, E. Lambooij, M. Nabuurs, E. Decuypere and J. Stegeman (2005). "Processing, products and food safety comparison of bruises and mortality, stress parameters, and meat quality in manually and mechanically caught broilers." Poult. Sci 84: 467-474.

PETA. (2011). "Top 10 reasons not to eat chicken." from http://www.peta.org/living/other/top-10-reasonseat-chickens/.

Qureshi, Z. (2016). Fast food chains urged to keep antibiotics off their menu. from http://pakobserver.net/2016/03/15/fast-foodchains-urged-to-keep-antibiotics-off-theirmenu/.

Rao, T. (1968). On the allocation of sample size in stratified sampling. Annals of the Institute of Statistical Mathematics 20(1): 159-166.

Recorder (2013). Poultry meat cheapest source of protein. Business Recorder. Lahore, Pakistan.

Reporter (2016a). Time to play a role in getting 'Antibiotics off the menu'. The News Online Islamabad, Pakistan, The Jang Group.

Reporter (2016b). Use of antibiotic in livestock, poultry industry affecting public health. The Dawn Online Islamabad, Pakistan.

ThePoultrySite. (2016). "Global poultry trendsDeveloping countries main drivers in Chicken consumption." Retrieved October, 2017, 2017, from

http:/www.thepoultrysite.com/articles/3588/glo bal-poultry-trends-developing-countries-maindrivers-in-chicken-consumption/.

Wegener, H. C. (2003). "Antibiotics in animal feed and their role in resistance development." Current opinion in Microbiology 6(5): 439-445.

Yamane, T. (1967). Sample size calculation, New York: Harper Press.

Zia, M. W. (2016). A source of quality protein. from http://pakobserver.net/2016/04/22/a-source-ofquality-protein. 